\title{
Correction to: Analytical and Clinical Performance of Droplet Digital PCR in the Detection and Quantification of SARS-CoV-2
}

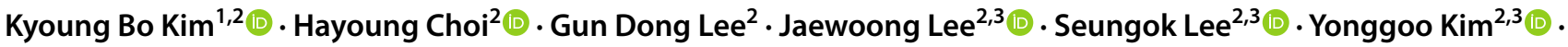 \\ Sung-Yeon $\mathrm{ChO}^{4,5} \cdot$ Dong-Gun Lee $\mathrm{C}^{4,5} \cdot$ Myungshin $\mathrm{Kim}^{2,3}$
}

Accepted: 5 September 2021 / Published online: 18 September 2021

(c) The Author(s) 2021

\section{Correction to: \\ Molecular Diagnosis \& Therapy (2021) 25:617-628 \\ https://doi.org/10.1007/s40291-021-00547-1}

The article Analytical and Clinical Performance of Droplet Digital PCR in the Detection and Quantification of SARS-CoV-2 written by Kyoung Bo Kim, Hayoung Choi, Gun Dong Lee, Jaewoong Lee, Seungok Lee, Yonggoo Kim, Sung-Yeon Cho, Dong-Gun Lee and Myungshin Kim was originally published Online First without Open Access. After publication in volume 25, issue 5 the author decided to opt for Open Choice and to make the article an Open Access publication. Therefore, the copyright of the article has been changed to @The Author(s) and the article is forthwith distributed under the terms of the Creative Commons Attribution.
Open Access This article is licensed under a Creative Commons Attribution-NonCommercial 4.0 International License, which permits any non-commercial use, sharing, adaptation, distribution and reproduction in any medium or format, as long as you give appropriate credit to the original author(s) and the source, provide a link to the Creative Commons licence, and indicate if changes were made. The images or other third party material in this article are included in the article's Creative Commons licence, unless indicated otherwise in a credit line to the material. If material is not included in the article's Creative Commons licence and your intended use is not permitted by statutory regulation or exceeds the permitted use, you will need to obtain permission directly from the copyright holder.To view a copy of this licence, visit http://creativecommons.org/licenses/by-nc/4.0/.

The original article can be found online at https://doi.org/10.1007/ s40291-021-00547-1.

Myungshin Kim

microkim@catholic.ac.kr

1 Department of Laboratory Medicine, Keimyung University School of Medicine, Daegu, Republic of Korea

2 Catholic Genetic Laboratory Center, Seoul St. Mary's Hospital, College of Medicine, The Catholic University of Korea, Seoul, Republic of Korea

3 Department of Laboratory Medicine, College of Medicine, The Catholic University of Korea, Seoul, Republic of Korea

4 Division of Infectious Diseases, Department of Internal Medicine, College of Medicine, The Catholic University of Korea, Seoul, Republic of Korea

5 Vaccine Bio Research Institute, College of Medicine, The Catholic University of Korea, Seoul, Republic of Korea 